On Wine, Globalization, and Glocalization : Long-Term Developments and Present-Day Controversies

\title{
Inglis, David
}

Brill

2021-12-02

Inglis , D 2021 , On Wine, Globalization, and Glocalization : Long-Term Developments and Present-Day Controversies . in P Beyer (ed.) , Globalization/Glocalization: Developments in Theory and Application : Essays in Honour of Roland Robertson . International Studies in pÿSociology and Social Anthropology, vol. 139 , Brill , Leiden , pp. 237259 . https://doi.org/10.1163/9789004500365

http://hdl.handle.net/10138/339023

https://doi.org/10.1163/9789004500365_014

cc_by_nd

acceptedVersion

Downloaded from Helda, University of Helsinki institutional repository.

This is an electronic reprint of the original article.

This reprint may differ from the original in pagination and typographic detail.

Please cite the original version. 


\section{On Wine Globalization and Glocalization: Long-Term Developments and Present-Day Controversies}

\section{Introduction}

Go into a well-stocked wine shop in the Developed World - and some parts of the Developing World - today, and you will probably see an apparently very diverse range of wines from many countries, a far more heterogeneous offering than would have been likely even just 20 years ago. You may see wines from seemingly unlikely locales such as Thailand, India, China and Brazil, alongside both the so-called classic regions of the European "Old World", as well as the newer, but nowadays firmly established and legitimated, wine-growing areas of the Americas, Australasia and South Africa. In certain specialist shops you may also find wines from the erstwhile peripheries of European wine-making, such as Wales, Belgium and Denmark, all beneficiaries - if that is the word - of rising temperatures which make winemaking possible now in these locations. The well-stocked shelves are testament to an important dimension of the globalization of wine, namely the multiplicity of current offerings and the increasingly disparate parts of the planet from which they hail.

But take a closer look, going beyond the dazzling diversity of wines available, and you will discern various recurring patterns which operate across regional and national borders. 12 to 14 percent alcohol volume is standard pretty much everywhere across the world, although some wine producing areas, such as Germany and Alsace, specialising in lower alcohol wines. Most of the bottles will be the same shape, with only some permissible and predictable regional variations, such as the distinctive long-necked bottles of Alsace or the flasks of old-style Chianti. These are shapes which producers in other parts of the world sometimes adopt for bottling their own wines, emulating the look as well as the taste of the products of their European competitors.

Almost all the bottles will be in globally standardized sizes, based on the core $75 \mathrm{cl}$ measurement. The labels on the fronts of the bottles will conform to a few basic visual types with widely replicated imagery, regardless of where in the world the wines come from - the Bordeaux chateau, signifying tradition, prestige and "class"; the rural setting of the vineyard, signifying earth-boundness, naturalness and authenticity; the cute animal branding, signifying fun and approachability; the cartoon of a defiant young woman, signifying non-conformism and "attitude"; and so on, in entirely predictable and homogenized visual patterns (Inglis, $2019 \mathrm{~b}$ ). Wine marketing is all about the supposed uniqueness of the wine itself and the terrain from which it came. It is nonetheless the case that the tropes of wine marketing, centred on notions of locality, are themselves highly standardized and globally present - a feature of wider cultural globalization that Roland Robertson has emphasized. The localness of wine from South Africa, for example, is presented in ways that are pretty much identical to the manners in which the alleged locality is sold for wines coming from Chile or Italy or wherever on the planet.

The liquid inside the bottles is remarkably similar too, regardless of where the grapes were grown and where the wine was made. Out of circa 10,000 possible grape varieties that wine could be made from today, only a very limited range are grown on a commercial scale (McGovern, 2003). While marketing stresses the differences between, for example, Chardonnay grown in Burgundy and that grown in California or Greece, when the remarkably limited number of grape varietals that are widely cultivated and sold as wine is taken into account, one can appreciate more clearly how homogenized the taste worlds of wine are today. There is not as big a difference between French and Greek versions of Chardonnay as there is 
between any sort of Chardonnay, wherever it comes from, and more obscure varietals that are indigenous to particular areas, but which have never become prestigious or fashionable, and therefore have never enjoyed any kind of wider presence beyond their own immediate locality. What most wine drinkers drink most of the time has tastes and organoleptic properties that are remarkably similar wherever the wines may happen to come from. Wine connoisseurship is essentially an exercise in finding dissimilarities between liquids that are in major ways remarkably similar, regardless of the specific geographical and cultural provenance which marketing does its best to highlight.

Wine today is therefore both deeply heterogeneous and notably homogenized. This is exactly the sort of situation that Roland Robertson's sociology of globalization has been highly attentive to. This is rooted in the fact that the wine industry itself is markedly globalized in multiple ways today, involving trans-national forms of production, distribution, mediation and consumption. At both the upper and lower ends of the price and quality scales, contemporary wine making, selling and drinking are shaped by, reflect and contribute to globalization dynamics.

Yet, as is the case in some other scholarly areas, the study of wine remains divided: between political economy of production processes and ethnographic analysis of consumers; between macro-level analysis of wine economies and micro-level analyses of specific sites of production and consumption; and between different disciplinary orientations, ranging from orthodox economics to social geography and anthropology, all with their own specific orientations and analytical blindsides (Inglis and Almila, 2019). The specifically sociological study of wine remains in its infancy, and one may well wonder why sociologists have been so reluctant to deal with wine in comparison to their social scientific brethren. As Robertson's sociology of globalization holds out the promise of a more truly trans-disciplinary and synthetic understanding of the multiple layers of global dynamics, and roots this orientation in a strongly historical perspective encompassing long periods of world/global history (Robertson, 1995: 35), then it seems appropriate to seek to give an account of the global - and globalized - wine world in a manner inspired by Robertson, which is exactly what this chapter endeavours to do. We will see what happens when some of Robertson's concepts and analytic dispositions are brought to bear on wine-related issues.

\section{History - The Proto-Globalization of Wine}

The grape vine is a globalized plant par excellence and has been so for several thousand years. Approximately 100 grape species grow wild across the world. Yet it is just one single Eurasian grape species, Vitis Vinifera L. subsp. Sylvestris, which is the source of $99 \%$ of the world's wine today. In its wild form it grows from Central Asia to Iberia, spanning a distance of circa 6300 kilometres, within a north to south band of about 1300 kilometres. All domesticated grape varietals derive from it. Generations of viticulturalists have exploited Vitis Vinifera's great potential for being altered, manipulated and transplanted to new places, often over very long distances (McGovern, 2003).

The earliest evidence of making wine from Vitis Vinifera grapes dates from about 6000 BCE, in the area of the Caucasus now called Georgia (Kassam and Davis, 2017). There was a wine industry in Egypt and Lower Mesopotamia circa 3000 BCE, which had spread westwards to Crete by 2200 BCE. In the second millennium BCE, Phoenician traders from Tyre and Lebanon took grape vines to North Africa, Italy and thence to Iberia. The descendants of the Phoenicians, 
the Carthaginians, had developed extensive wine-making knowledge by the $3^{\text {rd }}$ century BCE. Greek settlers colonized southern Italy in the $8^{\text {th }}$ and $7^{\text {th }}$ centuries BCE, planting so many vines there that the Greeks called southern Italy 'Enotria', the Land of Vines. Vines and wine-making techniques were also brought at that time to Sicily and the Black Sea (Millon, 2013).

Given both Vitis Vinifera's protean qualities, and the fact that the wine made from the plant's grapes has long-term storage potential, grape-based wine has historically been much more likely to travel over long distances as a circulating commodity than have beer and other fermented drinks, these generally being more for immediate consumption in the places they were made. The further afield wine travelled, the more likely it was to be a prestigious object of elite consumption, with lower social groups usually drinking more locally-sourced brews. Nonetheless, wine has had more capacities than other alcoholic beverages for making social and economic linkages between different places through being offered for commercial sale. It has also been less likely than other drinks to be made in contexts of simple domestic production, more often being made in specialized commodity production sites - wineries - which were often separate from the places where the drink was consumed (Dietler, 2006). Wine has thus for a very long time been a globalized and globalizing entity par excellence.

While wine has travelled, the various sorts of people involved with it have often thought in terms of strong symbolic connections between specific wines and specific places. It is a feature of human wine consumption over several millennia that the more wine travels to get to the consumer, the more there is likely to be dispositions by both sellers and recipients to want to identify its point of origin (Capatti and Montanari, 2003). For example, by the $3^{\text {rd }}$ millennium the writing on Egyptian wine jars, and the stamps on clay seals put onto the jars, sometimes indicated quite detailed information: the year of the vintage, the vineyard where the wine was made, the name of the vintner, and sometimes the perceived quality level (McGovern, 2003).

The Roman Empire, which made the whole Mediterranean its central highway, can be viewed as a major mechanism of the (proto-)globalization of wine. Within its massive territory, stretching from Iberia and Britannia in the West through to the Near East, there was a massive movement and churning-up of people, ideas, goods and commodities (Inglis and Robertson, 2009), including vines, wine-making techniques and finished wines. Such developments were in part made possible by the very large-scale transportation of wine-bearing amphorae all around the empire (Hingley, 2005). These vessels were mass-produced and came in standardized sizes, echoing the situation around the globe today (Pinney, 2005).

The Greco-Roman world understood the agricultural trinity of wheat, olives and wine as profound symbols of civilization (Serventi and Sabban, 2002). The planting of vines in new territories, and the subsequent adoption of a wine-drinking culture by the indigenous inhabitants in imitation of Roman practice, were important parts of the Romanification process. The presence of both wine making and imported wines could have major ramifications for how life was lived in a particular place. For example, in Roman-controlled Crete, the social elite were wealthy enough to create a market for imported wine. Simultaneously, the making of wine for export generated wealth which was then spent on consumer goods like lamps and other household items, made in the then-current 'international' style favoured in Rome, which in turn lead to the taking up of cross-empire fashion trends (Sweetman, 2007).

With very large amounts of wine being transported, more land was put under vine, at one point taking up to $85 \%$ of all cultivated land in Italy. Wine production required constant and intensive labour, and so slaves were more effective than free labour in producing it. As more parts of the Italian countryside were turned over to vines tended by slaves, the free peasantry increasingly migrated to the cities, especially Rome itself. This was part of a great movement of millions of 
people from countryside to urban areas spanning the $2^{\text {nd }}$ and $1^{\text {st }}$ centuries BCE, a relatively rapid and certainly vast urbanization process that was not to be matched until the massive rises in London's population more than 1500 years later. In this period of economic boom, the richest landowners who owned vast vineyards became even richer, with massive socio-economic inequalities being created (Geraghty, 2007). This process bears comparison with the generation of massive inequalities, especially in huge cities, through the neo-liberalized globalization processes which have been afoot in our own time since the late 1970s (Sassen, 2001). In both periods, wine production, distribution and consumption have been intimately tied up with changes in the urban fabric, and the creation of richer social strata with a thirst for wine, made for them often by farm-workers operating in conditions of sometimes extreme exploitation, a situation that continues today (Crenn, 2015).

The Romans had a keen sense of the geographical provenance of wine. Elites thought of good wine as something that came from specific noteworthy regions. These were all in Italy and the Greek islands. Pliny noted that the world's vineyards produced 195 different kinds of wine, and double that number of grape varieties (Soyer, 2004 [1858]). He noted that two-thirds of the greatest producing regions were in Italy. He also pointed out that the wines of Campania were famous across the whole known world, indicating that the concept of global reputation for especially fine wines is not new (Geraghty, 2007). Elite drinkers at formal dinners liked to alternate between Italian and 'foreign' wines, the latter being called transmarina (from across the sea), these being brought from Greece and Asia Minor (Dalby, 2000). Wines therefore expressed 'Western-ness' and 'Eastern-ness', in some manner akin to the ways that wine discourse today distinguishes between so-called 'Old World' and 'New World' styles.

Product differentiation was already paramount at this period. Wines from the island of Cos, which were highly rated, came in distinctive shapely amphorae, recognised by connoisseurs the empire over. This design was copied by unscrupulous merchants from all over the region, to sell inferior wines from elsewhere as if they were from Cos (Dalby, 2000). Selling inferior products that could have come from anywhere, packaged as superior items that purport to come from a reputed region, has continued to be a big problem for both sellers and consumers down through the centuries (Dalby, 2000). Cheaper bulk wines from the eastern Mediterranean intended for long-distance travel to western parts of the empire usually had spices added for preservative purposes. Keeping wine from spoiling while it travels over long distances has prompted different sort of technological fixes at different times. Spice was initially added in Greek and Roman times as a preservative, but then drinkers got a taste for it, so it was added also for aesthetic reasons. This is an ancient anticipation of different sorts of modern technological interventions to make wine appeal to the mainstream palate of the time, those palates themselves being trans-local and dispersed over often large distances (Lukacs, 2012).

The Roman empire is but one instance of the travels of vines and wines being made possible by the political, economic and social structures of empire, both in the west and east of Eurasia, wine's so-called Old World. Wines made in the Fergana Valley in central Asia were reputed to be excellent, attested to both by the Roman geographer Strabo and a Chinese contemporary, indicating the geographical and cultural extent to which reputations for quality could travel even 2000 years ago (McGovern, 2003). Marco Polo wrote that the noted wines of Shanxi province were to be found across China. The Moghul empire in the $16^{\text {th }}$ century CE was kept supplied by wineries in the Indus Valley and Afghanistan (Anderson, 2004).

Both religious beliefs and wines have travelled through and between empires (Beyer, 1994), and the connections between wine and the world religions can be briefly noted. Part of the story of the decline of the Roman empire is the rise of Christianity within its heartlands and throughout the provinces, and then the subsequent rise of Islam in the regions to the east. The 
extensive geographical spreading of the world religions have been powerful globalizing and glocalizing forces (Robertson, 2015). After the so-called Fall of Rome, much wine-making knowledge was kept alive for the next 1500 years by the inhabitants of Christian monasteries. Some of these operations continue even now, mostly in Germany, some exhibiting nearly 1000 years of unbroken wine-making practice (Millon, 2013).

Christianity has oscillated in its attitudes towards wine. In its earlier phases there was an 'intense [and trans-national] propaganda campaign in favour of wine as both an alimentary symbol and a ritual tool of the new faith' (Montanari, 1996: 122-3). The earliest driving force behind the transplantation of grape vines from Europe to the Americas and East Asia was the need to have communion wine for the new churches and monasteries of Christian migrants. Spanish Jesuits began wineries in Peru in the $17^{\text {th }}$ century, while Franciscan monks did the same in Mexico, and then in California, in the late $18^{\text {th }}$ century (Colman, 2008). Christian missionaries took wine-making skills with them to China in the late $19^{\text {th }}$ century, literally sowing the seeds of today's burgeoning Chinese domestic production of wine (Kjellgren, 2019). Conversely, Christian thought sometimes redefined wine as a drug to be avoided and renounced. Prohibition movements in the later $19^{\text {th }}$ and early $20^{\text {th }}$ centuries helped to seriously undermine the US's nascent wine industry, which would not come back to life in significant ways until as late as the 1970s (Taplin, 2019).

If Christianity has at different times and places both stimulated and prohibited making wine and sending it travelling, the case of Islam is less ambivalent. The Islamic prohibition on making and drinking wine took out large areas which had previously had wine production for many centuries, including in Syria, Jordan, Anatolia, Egypt and Arabia. Yemen, for example, at one point exported wine to India, but the turn to Islam stopped that trade altogether (Hyams, 1965). Wine drinking survived for quite some time in Persia, as the odes to the joys of the drink written in medieval Persian poetry attest. Sometimes wine drinking continued, but unofficially and by illegal means. There is evidence that in the late medieval period, wine was smuggled by Genoese traders from Cyprus and Crete to elites in Egypt. The remainder went to westerly markets as far afield as London (Hyams, 1965). In the long-term, the Islamic prohibitions on wine concentrated wine-making primarily in the western reaches of Eurasia, rendering it into a specifically 'Western' practice surrounded by distinctive cultural norms, and obliterating other, older wine cultures of places further east on the continent.

Over hundreds of years, vines and wines travelled up the major European rivers, eventually reaching central Europe (McGovern, 2003). These rivers were some of the most important highways of the time, with human trade involving the carrying of both wines and vines along them. By the medieval period, the major wine routes were strongly dependent on water-borne transport. The major routes for distributing wine were from the Mediterranean by sea and land to Poland and the Baltics, the southern German trade via the Rhine to Northern Germany and Scandinavia, and the sea trade from Western France to England and Flanders (Phillips, 2000).

Wine in medieval Europe was often bitterly complained about because of spoilage problems. Barrels - which had replaced ancient amphorae as the solution to making wine portable (Murray, 2001) - were often poorly sealed and the wine inside would rapidly oxidize, making it taste very unwholesome. Even when barrels worked properly, once they were opened the wine was good for only a few days before turning sour. French commentators singled out the badness of wine drunk in England. In that country, spoiled royal stocks were sometimes given to the poor, in order to use it up. In the year 1374 the English king Edward III allowed a Great Yarmouth merchant to avoid the ban on exporting wine from England, to send twenty casks of 
spoiled Gascon wine, which even the London poor would have turned their noses up at, 'to the less discriminating drinkers of Scotland and Norway' (Turner, 2004: 131).

\section{Towards Modern Wine Globalization}

There is a case to be made for saying that wine moves from situations of proto-globalization to globalization proper only at the point when its trade becomes oceanic in scale, that is when oceans, rather than rivers, become the main highways for wine. Slowly but surely from the $16^{\text {th }}$ century CE onwards, the now navigable oceans became key means of transporting plants and finished wine products around the world. The advent of the new transportation technology of the glass bottle and cork in that century made a shift from river- to ocean-based trade possible (Millon, 2013). The new means of transportation meant that novel areas were opened-up for wine production, while entrepreneurs began to discern that substantial profits could be made out of those regions. Vineyards were developed in the Dutch colony of the Cape in southern Africa in the $17^{\text {th }}$ century, and Constantia wine quickly developed a high pan-European reputation (Unwin, 1991).

The Portuguese-controlled island of Madeira became a significant wine-producing location after the colonial sugar cane trade had been shifted to the Caribbean and Brazil (Murray, 2001). Madeira was an important locale for the trans-Atlantic wine trade, which was highly developed by the late $18^{\text {th }}$ century. Firms located in Madeira had commercial contacts that stretched from Edinburgh and London to Kingston in Jamaica, New York and Bengal. Actors in their oceanspanning networks included North American farmers (whose grain might be traded for wines), Swedish barrel-makers (who made the containers that made trans-Atlantic trade possible), and French brandy exporters (whose product was added to the wine to stabilize it on its travels), as well as buyers and consumers in European and colonial markets (Hancock, 1998, 2003). What we now think of as distinctively 'Madeira' wines were in fact created out of the pragmatic dynamics of oceanic trading conditions. As producers, traders and far-flung consumers communicated with each other, new demands were created, and production soon followed suit. For example, how much brandy was used to fortify the wines was varied according to the tastes of different sets of far-off consumers: less was added for drinkers in the warmer climates of the Caribbean colonies and the southern states of the US, while more was added for those in the northern states. As the wines travelled, they experienced very high temperatures in the ships' holds. Buyers reported that they preferred the taste of wines that had made particularly long and hot voyages. Traders therefore started to send ships the longer way around to Europe, either via the West Indies or India, creating a globe-spanning circuit of 'floating ovens'. Then, in order to reduce costs, new heating technologies were introduced to Madeira wineries, speeding up the maturing process by reproducing long-distance travel on dry land in a fraction of the time it would have taken otherwise (Hancock, 1998, 2003).

The $19^{\text {th }}$ century, especially in its last few decades, was the period when the patterns to be found in the later $20^{\text {th }}$ and early $21^{\text {st }}$ century wine world were established (Simpson, 2001). The spread of European wine-making across the globe was part of broader processes of colonization, and the mass migrations that went together with them. Robertson (1994: 44) notes the formative role of late $19^{\text {th }}$ century moves to link localities and create global unicity, and the beginnings of moves to asserting particularities in globally shared and recognisable ways, such as at international exhibitions (Robertson, 199536 ). These were venues at which, in fact, some of the world's earliest world-level wine prizes were doled out, a significant index of wine world globalization in itself (Unwin, 1991). 
As many as 100 million people migrated in the $19^{\text {th }}$ century, half of them Europeans (Held et al, 1999). A significant number of these drank wine in their countries of origin, taking their tastes with them across the seas. A much smaller, but still significant, number also took winemaking skills with them, such as the Spanish and Italians who migrated to Argentina, Chile, Brazil and the United States. As new vineyards appeared across multiple continents, this led to a significant diversification in the world production of wine, as well as much more production by volume (Pinilla and Ayala, 2002).

For example, wine-making German, Swiss and Dalmatian colonists were introduced to Australia from the 1830s onwards, by British colonial authorities seeking to supplant France as a major source of supply for the mother country (Unwin, 1991). The first Italian winemaking migrants, many from Piemonte, arrived in California after Italian unification in the 1860s (Cinotto, 2012). They were able to get Italians from other regions to work for them for relatively low wages, while also exploiting an expanding Asian and Mexican workforce, a recurring story in Californian wine-making history (Peck, 2009). Already in the 1870s California wines were being exported to places as diverse as Australia, Peru, China and Denmark, while being shipped to the US East Coast in bulk, in containers that could hold 100 thousand gallons (Unwin, 1991).

The appearance of vineyards in the New World was never just for religious or commercial reasons only; wider considerations of 'civilization' were also at work. Thus, in $19^{\text {th }}$ century California, an animating force behind planting vines and getting the local population to drink wine rather than hard spirits, were elites' notions as to the 'civilizing' of the West of the continent, and the need for the newly elite US state, which nurtured its own imperial ambitions, to have a wine culture as sophisticated as that of the Romans 2000 years earlier. Similar ideas were at work among the British administrators of early $19^{\text {th }}$ century Australia. It was thought that viticulture allowed the landscapes of newly conquered territories to be located within a Western imperialist narrative of world history, which 'claimed that all powerful nations, since antiquity, had transcendent grape cultures'. Planting vines and making and drinking wines was part of 'an international set of colonial tactics for transforming landscapes and for propagating a particular worldview of cultivation and control' (Hannickel, 2013: 15).

The colonial spread of wine-making had major effects on the scale of production. As a general rule we can say that, when new territories for wine-making were opened-up by colonial expansion - as in such chronologically and geographically diverse cases of ancient North Africa by the Romans, and 19th century Chile by European immigrants - the scale of wine production tended to become much larger than in areas, such as much of Western Europe since the medieval period, where a free peasantry owned small-holdings over multiple generations. At the time of the emperor Nero, only six big proprietors controlled all wine production in Roman North Africa. This was a situation of massive concentration mimicked by the French experience in that region two millennia later (Johnson, 1989). Just as the Romans had set up that area as a massive source of wine production, so too did the late $19^{\text {th }}$ century French develop the Muslim-majority colony of Algeria as a major source of wine supply, as well as Tunisia and Morocco (Pinilla and Ayala, 2002). As the local peasantry were thrown off the land in favour of a small number of large industrial wineries owned by big companies, French colonial wine production in North Africa jumped exponentially, from a million hectares under vine in 1885 to 8.4 million hectares in 1910 (Simpson, 2011).

The cheap, crude bulk wine from the Maghreb fed rising lower-class demand in the cities of metropolitan France, while often being mixed into the wines of the French provinces, the resulting concoctions often being mis-sold as the genuine article from established regions like Burgundy and the Rhone. However, colonial expansion did not necessarily lead only to massive 
production by huge companies. It could also entail the introduction to new areas of peasant small-holders with tiny wine businesses, as was the case in $19^{\text {th }}$ century Argentina (Simpson, 2011). It could also lead to smaller-scale, high quality production. Thus, the French established wineries in the Lebanon, where some very fine French-style red wines are still made today (Hyams, 1965). In these various ways, patterns of wine-making were established in the $19^{\text {th }}$ century which still influence world-wide production today. In most regions, tiny independent businesses sit next to domains owned by vast multi-nationals, and mass market bulk wine is sourced from areas which also yield highly prestigious and expensive example of the winemaker's art (Lukacs, 2012).

\section{Wine Globalization Today}

Since the late 1970s, the production and selling of wine have been thoroughly bound up with broader processes of neo-liberalization of the global economy (Harvey, 2007). Neoliberalization has meant increasingly lowered national governmental tariff protections of domestic wine production, with wine producers becoming ever more directly exposed to global market forces. Some actors have been able to take advantage of these, while others have suffered seriously or gone out of business altogether. There has also been since the late 1970s a complexification of patterns of investment and ownership, with greatly increased levels of investors and owners coming from outside of the locales where grapes are grown and wine is made (Curran and Thorpe, 2014).

Massive corporate entities like Diageo and Constellation Brands have engaged in corporate take-overs of well-known wine-making operations like Mondavi in California and Mouton Cadet in Bordeaux. The French luxury brands conglomerate LVMH, which sells handbags and perfumes as well as wine, owns properties on five continents. Their luxury branded Champagnes and cognacs are sold across the planet in upscale retail outlets and airport duty free lounges, the non-spaces of the global retail economy (Augé, 1995). Apparently independent smaller-scale wineries are often owned by corporations, although the branding usually implies otherwise (Pinney, 2005). The American giant Gallo makes eight times as much wine every year as do all the regions of New Zealand put together (Veseth, 2012). Originally highly localized enterprises like the Tuscan Antinori family business now own properties in countries as diverse as the US, Chile, Hungary and Romania. Bordeaux- and Champagne-based operations have invested in places like California and Argentina (Lukacs, 2012).

The tide began to turn in favour of New World producers and against Old World ones from the 1970s, accelerating rapidly in the 1980s and 1990s. Californian wines started to enjoy newfound prestige against French and other established-region competitors (Taber, 2005). The rise to prominence of Australian wines was partly due to a process which neo-liberal doctrine is otherwise deeply suspicious of, namely State intervention and planning. The Australian government promoted policies whereby the national wine industry would aim first for more volume of exports to target markets like the UK, then secure rising value per bottle, and then achieve overall pre-eminence over Old World producers. This strategy was copied by other governments and national industries, such as in South Africa (Ewert and du Toit, 2005) and Chile, illustrating a broader issue to do with policy convergence across nation-states, operating through processes of diffusion, imitation and emulation, processes noted by Robertson (1995: 41). 
At the present time, the so-called Old and New Worlds of wine are bound up with each other in multiple and complex ways. In and through the densely inter-connected locales of the globalized wine world (Lagendijk, 2004), wine-making information flows from and to multiple locations, both cores (e.g. Bordeaux, California, Tuscany), semi-cores (e.g. the Languedoc), and peripheries (e.g. Macedonia). Highly educated and mobile personnel, trained in institutions in core areas, constantly traverse Old and New World regions, taking knowledge back and forth, and disseminating it through multiple pathways, sometimes fitting in two harvest seasons a year by flitting between hemispheres. This is just one aspect of the radical de-localization of wine-making knowledges and practices (Anderson et al, 2004).

The contemporary wine world entwines in multiple ways capitalist relations of production and ownership in agri-business, techno-science, distribution networks, the cultural industries of marketing and promotion, and the leisure industries. The very largest corporations have interests in all these domains. Large-scale farming (with often unfortunate environmental consequences, including soil erosion) and techno-scientific manipulation of both vines and wines operate together to create products of different quality levels (from very basic table wine to super-premium, highly expensive offerings) and endowed with variant symbolic connotations (Gwynne, 2008).

For large-scale, mass-market producers today, producing wine to be found on supermarket shelves in many countries, wine 'quality' is defined as equalling 'predictability, consistency and over-delivery' (Pont and Thomas, 2012: 643). This way of thinking involves ever higher levels of measurability and control in both vineyard and wineries. This is a specific version of broader 'McDonaldization' trends, whereby every part of a production process is engineered to fit tightly defined templates (Ritzer, 2007). Standardized industrial wine-making across the world today involves such factors as common trellising and irrigation systems, the planting of vines at prescribed distances from each other, more intensive pruning earlier on in the growing season, delaying of the harvest to maximise ripeness of berries, the use of stainless steel tanks for fermentation (allowing dry wines to be made in warm or even hot climates), precisely managed induced malolactic fermentation and the use of artificial yeasts, and widespread use of imported French oak barrels for maturation and storage. There has been a concomitant massive growth in the barrel-making industry (Colman, 2008).

Mass market wine the world over today exhibits pronounced levels of homogeneity of taste and character. Driven by techno-scientific interventions in the service of perceived consumer demand, 'case one taste[s] the same as case one million' (Colman, 2008: 104). Such wines are aimed at an increasingly universalized "global palate", characterised by low acidity, soft tannins and textures, relatively high residual sugars, forward fruit flavours, simple taste components, general "easy drinking" characteristics, and the option of being consumed without or without food. Such wine is thought to be makeable anywhere, regardless of the terrain, as long as certain prescribed production practices are followed (Lukacs, 2012).

This sort of wine is distributed around the world in large shipping containers with massive bags inside them (Murray, 2001). Such shipping methods have allowed for the bulk transportation of even the cheapest wines in the world, which previously no-one would have thought it worthwhile to sell it much beyond its region of origin. Hence cheap Chilean wine sent in bulk to China may end up labelled as 'Chinese wine' when it reaches its destination, while red wine sold by a California-based brand may actually come from less prestigious parts of France and Italy (Veseth, 2012). 
If wines are often made in very similar ways regardless of locality, so too are the grape varietals which are being grown in such places subject to, and expressions of, globalization dynamics. The planting from the 1980s onwards of the now-ubiquitous 'international' varietals, such as Cabernet Sauvignon, Merlot, Pinot Noir and Riesling, massively sped up what had hitherto been often slow processes of dispersal of varietals across regions, countries and continents (Lagendijk, 2004, Pinney, 2005). The new arrivals have often been planted at the expense of uprooting varietals that might have been grown in a region for decades or even centuries, but which had come to be regarded as lacking global name recognition and therefore market value (Gade, 2004). But planting globally recognisable varietals can be a perilous enterprise, There is no guarantee than a vineyard planted with, say, Chardonnay vines now will be profitable in 5 years' time or more (the point when viable wine can first be extracted from the grapes), as increasingly fickle markets and consumer preferences may have changed dramatically by then, rendering void the investment (Ewert and du Toit, 2005)

The more wine-making has been oriented to exports travelling very long geographical distances, as well as potentially great cultural distances too (as in the case of, say, selling Argentinian wine in Japan), the less direct connections there are between producers and consumers. Both the design of the wine itself (in terms of colour, flavour, aromas, alcohol level and so on) and the marketing of it (in terms of how the product looks, and what information is given on the labelling) seeks to bridge such gaps, allowing the products to travel to highly defined consumer groups, oftentimes on the other side of the world (Pont and Thomas, 2012).

Wine is marketed through an increasingly globalized system of labelling semiotics. These involve bold colours, easy-to-read text with standardised stories about flavours and the supposed natural endowments of the places of production, and the foregrounding of one of the internationally recognisable grape varietals on the front (Veseth, 2012). Such labelling stands in stark contrast to the old-style cryptic labels of some Old World producers, especially in France, which required higher levels of cultural capital on the behalf of consumers to decipher which grapes may have been used and what the wine actually tastes like (Peck, 2009). But even more 'accessible' labelling, beyond that for very basic branded wines, is meant to tell a story about the allegedly place-based nature of the wine in the bottle or box. This means that locality must be foregrounded in both visual and textual ways. Yet as Robertson (1994: 40) points out, the world of marketing is populated by experts who promote putative uniqueness by using standardised templates recognisable in most, if not all, parts of the world. So standardised imagery of chateaux can equally well be used to represent a locality in Bordeaux - the original font of such symbolism - or in China (especially as the Chinese now build simulacra of Bordeaux chateaux to promote indigenous wine-making - Kjellgren, 2019). Globallyrecognisable imagery of bodegas can be used to give a sense of place for Spanish or Californian wine. Universally utilisable scripts about provenance, authenticity and tradition are deployable on bottles from Patagonia and Georgia (Inglis, 2019a). These generalised 'recipes of locality' (Robertson, 1995: 25-26) are parts of much broader cultural processes whereby "variation is systematically produced' today (Roudometoff, 2015: 9).

Even if much of the wine sold around the world today is to a great extent a homogenized 'global' product today, made within the impersonal confines of capitalist agri-business and manipulated vastly in the laboratory, the selling of it very much involves glocalizing processes too (Robertson, 1992). The same wine may be framed differently to different sorts of people in different sorts of places. Selling a given Chilean wine in Singapore may be a rather different 
endeavour in terms of symbolism and framing than it would be in Finland, for example. These are signs of what Roudometoff (2015: 7), following Robertson, calls the "effervescence of (g)locality". For example, purveyors of white wine find it notoriously difficult to sell to the red wine-imbibing nouveaux riches and aspirant middle classes of Hong Kong and the People's Republic of China, because white is not a lucky colour in the way red most emphatically is. Local and national understandings of what is good to drink continue to clash, or at least mingle uneasily, with the globalized semiotics of the contemporary wine industry (Kjellgren, 2019, Ho, 2019).

\section{Terroir and Globalization}

The greatest controversies in the globalized wine world today concerns the vexed issues surrounding terroir, which at root is the notion that wine expresses, or should express, some essential qualities of the terrain in and through which it was made (Black and Ulin, 2013). A key line of fracture operates between two (highly internally differentiated) sets of actors, each taking up pro- and anti-terroir rhetorical positions. These basic dispositions play out in multiple ways across multiple locations around the world today.

The first grouping involves those who believe that terroir wines and wine-making are under threat from the homogenizing forces of what they often frame as 'globalization', mostly meaning huge companies making characterless, apparently place-less wine. For this grouping, the globalization of wine is taken to mean the production of ever more standardised wines that all taste roughly the same, and therefore could be made anywhere. This is thought to seriously threaten the existence and integrity of wines that truly express a particular terroir, that is, wines that have definitely come from somewhere.

Pro-terroir, anti-globalization viewpoints have been amplified by high-profile interventions in the media, notably American film-maker Jonathan Nossiter's widely viewed and highly polemical pro-terroir documentary film Mondovino (2004). For Nossiter, 'the barbarism of the new globalization' means that 'almost three quarters of the wines [made] in ... the winemaking regions of the world, are produced with total or near-total cynicism by industrial hawkers, false artisans, or misanthropic (or feud-ridden) family estates' (Nossiter, 2009: 90, 55). Mass-market branded wines made through techno-scientific manipulation destroy the economic basis of terroir production, and without terroir-oriented wine-making 'there is no individuality, no dignity, no tolerance, and no shared civilization' (Nossiter, 2009: 11). The controversies that Mondovino both crystallized and further provoked have had multiple effects on the global wine world, helping to structure how debates in it have been subsequently framed. Mondovino is simultaneously a representation of what it defines as 'globalization', a striking intervention in wine world controversies, and a structuring agent generative of further controversies and framings of them (Barthel-Bouchier and Clough, 2005).

The second grouping, involving wine world actors working for or supportive of big industrial concerns, as well as some wine scientists, by contrast believes that terroir is over-rated as an idea, and is often a marketing scam, which fools consumers into paying higher prices on spurious grounds of claimed 'authenticity'. Some argue that the notion of terroir is simultaneously both essentialising - it fabricates a homogeneous entity that does not really exist - and vague - products of a given terroir are usually known not by what they are but by what they are not. When asked, even small-scale producers who might be expected to be 
experts on their own area, can struggle to say exactly what their terroir 'is', but they can say that their wines are not like - they are not like the wines of some other terroir (Parker, 2015). Critics also allege that terroir ideas imply a kind of environmental determinism - somehow the earth 'speaks' through the wines. It then becomes potentially awkward for the wine-maker to describe their own role in the process. Are they just 'mid-wives', allowing the terroir to speak for itself? If so, how does one account for the fact that the wine-maker is actively involved in all sorts of ways in making the wine? What about her agency, and the array of scientific knowledges and technological devices she uses to bring the wine into existence? What if wine is less made in the vineyard than in the techno-scientifically sophisticated winery (Matthews, 2015)?

Wine marketing - the scripts of which have been globally spread - frequently utilises terroir imagery, and often implies that wine has been made in a particular place, in the ways it currently is made, since time immemorial. But this disguises the scientific and technical basis of most modern wine-making (Beverland and Luxton, 2005). According to some, terroir thinking is mostly or wholly a marketing strategy (Laudan, 2004). It helps producers and marketers project onto potentially global markets and cultural circuits images of a special and essentialized sense of place. As those images circulate around the world, the place is apparently decommodified (this is wine made by tradition and out of love, not for profit), and yet the terroir imagery helps fetch higher prices for the wine than if it had not been sold that way. Terroir is a way of constructing the 'local' in order to circulate it globally and to accrue profit from it (Heath and Meneley, 2007).

One reason for the bitterness of disputes over the nature and benefits of terroir may reside in the fact that the term means different things to different people. The phrase has fluid and multiple meanings, even within its birthplace of France. As it has spread around the world, it has become ever more polysemic. A tendency in the US is to understand it as referring primarily or exclusively to the properties of the soil in which the vines grow. French meanings, however, involve the multivalent idea of 'place', which encompasses physical, geographical, cultural and historical facets (Trubek, 2004).

It is obvious that terroir is an important element of those sorts of globalized scripts, noted above, which sell locality, as a glance at the term's ubiquity on wine labelling from across the world attests (Inglis, 2019a). Moreover, following Robertson (1992), globalization processes can be understood to involve simultaneously both homogenization - more sameness everywhere, and, crucially, more perceived sameness - and also heterogenization and the production of differences too. The latter is in part produced by actors responding to what they perceive of as often threatening homogenization. Each set of processes is 'complementary and interpenetrative', rather than simply antagonistic (Robertson, 1995: 40). The 'local' is constantly (re-)constructed in, through and in response to the perceived 'global', especially in its more apparently homogenizing guises.

Examining wine-making in this light means seeing how ever more wines are self-consciously understood by ever more makers - and then others sorts of actors too, including consumers - to be 'different' in one way or another from every other wine made around the planet, because of its rootedness in a terroir. This form of heterogenization is therefore produced by one dimension of globalization, namely the planet-wide dispersion of ideas that wine must express terroir if it is to be any good at all. With the dispersion of that idea pretty much everywhere where wine is grown (and consumed as well), comes also the attendant notion that such wines 
may be under threat by another dimension of wine globalization, namely the tendency towards making mass-market wines that have no discernibly individual character at all. In other words, ideas as to terroir are indissociable from fears as to the destruction of terroir, as both notions are spread around the world in tandem, rather than terroir being somehow primal and fears for its future following on at a later date. Instead, the fears about terroir's viability can be seen as a constituent element of the notion itself.

The ubiquity and taken-for-granted nature today of terroir ideas across the world is itself a sign and product of globalization, as well as a stimulant of further globalization. The term was not used much in English language discussions of wine until 1980s, at which point its usage rose hugely (Matthews, 2015: 148). Terroir ideas have travelled the world from their birth-place in France and have been strongly globalized, nowadays constituting an international cult of terroir' (Hannickel, 2013: 12). The very idea of terroir has itself spread globally, and that is as much both part and result of wine globalization as are trends towards wines that seemingly all taste similar regardless of which region or country they were made in. In a Robertsonian sense, 'globalization' and 'terroir' are therefore not simply opposites, even if politicized rhetoric in the wine field often constructs things that way. When people in a particular place worry that the wines made there may lose their special terroir-based characteristics, as wine production becomes seemingly ever more globalized, what they will most likely not be fully aware of is that it was already as a result of globalizing forces that the very notion that wines in that place express a terroir will have arrived in that location in the first place and subsequently become influential there (Inglis, 2019b).

The globalization of wine has involved both the spread of terroir ideas around the planet, and the sorts of production processes that seem to threaten terroir wines so dramatically. A curious feature of wine globalization today, then, is that a lot of people experience it is a period when 'classical' French notions about wine and wine-making are being undermined by 'globalization'. Yet over the last century there has been, and this is still continuing today, a very profound global spreading of French ideas about terroir.

A further notable aspect of the global spread of terroir ideas is that, as wine-makers start up new vineyards, they have a limited set of choices as to how to present to the world what their terroir is and what sorts of wines it produces. They can claim that the terroir is wholly unlike any others; or they can say that it is like, perhaps very like, a pre-existing terroir in an established region; or again they can say that it is a mixture of the previous two possibilities, being very akin in some ways to an established region, but with its own distinctive characteristics too. All these positions allow for potentially effective selling on national and world markets.

A good example of the third position can be seen in the presentation by groups of wine-makers in Northern California of their terroir and their wine-making style as 'Cal-Ital', which is said to combine distinctively New World (Californian) and Old World (Italian, especially Piemontese) features in a hybrid that is itself unique (Helzer, 2001). As the mixing and melding of different cultures is one often-observed feature of broader trends of cultural globalization, the invention and presentation of hybrid terroirs today is not very surprising. Such hybrids are not formulated as either one thing or the other, but instead are proudly displayed as exhibiting the best of both worlds. Self-conscious beliefs as to the hybrid nature of a terroir can have very material effects. The belief in the uniqueness of Cal-Ital terroir has motivated the planting in the region of classic Central and Northern Italian varietals like Sangiovese and Barbera, as 
well as some lesser known regional Italian varieties (Helzer, 2001). In this way, terroir beliefs become self-fulfilling prophecies: the assumption that a terroir is like it is, or should be like what it is imagined potentially to be, leads to practices which are aimed at bringing that very terroir into tangible, and hopefully profitable, existence. Terroir ideas the world over today in that sense are 'performative', for they can bring into being that which they purport merely to describe.

Especially over the last decade, canny marketing has been able to present to a global audience of connoisseurs, especially of the hipper type who greatly prize 'authenticity' in their drinks, apparently very local grapes and wine styles, selling these as unique and far more interesting than just yet more standardised Cabernet and Chardonnay. In this way, wine globalization can be said to encompass both the destruction and the revitalization and reinvention of very regionalised varietals and the ways of making wine (apparently) traditionally associated with them (Lukacs, 2012). The recent rise to prominence among hipster drinkers in places like London and New York of the once relatively obscure varietals and challenging-tasting wines of the Jura region in eastern France is a good case in point. The imagery and typefaces of selfproclaimed artisanal bottles have also been trans-nationally spread, with established ways to project authenticity being used by producers from Argentina to Hungary (Meneley, 2007). Such devices are intended to appeal to urban, upper middle-class consuming publics that are noticeably similar across countries and regions of the world (Field, 2008).

\section{Conclusion}

In this chapter we have examined major features of the historical and contemporary globalization of wine, talking some inspiration from some of Roland Robertson's sociological vocabulary and thematic emphases. While examining wine globalization through some Robertsonian lenses is interesting and productive in itself, it is probably the Robertson-inspired elucidation of some of the ambiguities of, and knotty problems connected with, the vexed notion of terroir that is the most valuable outcome for the contemporary analyst of wine matters in the world today.

I can end by saying that one of the most pleasing coincidences that a sociologist of wine can point to is that while (Bad) Durkheim is the name of one of Germany's most venerable winegrowing sub-regions, so is Robertson one of the major wine areas of South Africa. Thus it happens to be that two major sociologists - one of whom was certainly inspired by the other share their names with two of the most distinguished vinicultural locations globally, one in the so-called Old World and one in the New. This serendipitous nomenclature should stand as an inspiration for those interested in developing further the sociological study of globalizing wine. It is certainly more propitious than merely relying on the conceptual flavour-world of wine from a Chateau named Latour, which is all initial overpowering flowery bouquet, followed by lack of substantial body, genuine aging potential, and any sort of satisfying finish on the intellectual palate... 


\section{References}

Anderson, K. (2004) 'Introduction', in Anderson, K. (ed.) (2004) The World's Wine Markets: Globalization at Work, Cheltenham: Edward Elgar, 3-13

Anderson, K., Norman, D. and Wittwer, G. (2004) 'The Global Picture', in Anderson, K. (ed.) (2004) The World's Wine Markets: Globalization at Work, Cheltenham: Edward Elgar, $14-58$

Anderson, K. and Pinilla, V. (2018) Wine Globalization: A New Comparative History, Cambridge University Press

Augé, M. (1995) Non-Places: Introduction to an Anthropology of Supermodernity, London: Verso

Barthel-Bouchier, D. and Clough, L. (2005) 'From Mondavi to Depardieu: The Global/Local Politics of Wine', French Politics, Culture \& Society, 23(2): 71-90

Beverland, M. and Luxton, S. (2005) 'Managing Integrated Marketing Communication (IMC) through Strategic Decoupling: How Luxury Wine Firms Retain Brand Leadership while Appearing to Be Wedded to the Past', Journal of Advertising, 34(4): 103-116

Beyer, P. (1994) Religion and Globalization, London: Sage

Black, R. E. and Ulin, R. C. (eds.) (2013) Wine and Culture: Vineyard to Glass, London: Bloomsbury

Capatti, A. and Montanari, M. (2003) Italian Cuisine, New York: Columbia University Press

Cinotto, S. (2012) Soft Soil, Black Grapes: The Birth of Italian Wine-Making in California, New York: New York University Press

Colman, T. (2008) Wine Politics, Berkeley: University of California Press

Dalby, A. (2000) Empires of Pleasures: Luxury and Indulgence in the Roman World, London: Routledge

Dietler, M. (2006) 'Alcohol: Anthropological/ Archaeological Perspectives', Annual Review of Anthropology, 35: 229-249.

Ewert, J. and du Toit, A. (2005) 'A Deepening Divide in the Countryside: Restructuring and Rural Livelihoods in the South African Wine Industry', Journal of Southern African Studies, 31(2): 315-332

Gade, D. W. (2004) 'Tradition, Territory, and Terroir in French Viniculture: Cassis, France, and Appellation Contrôlée', Annals of the Association of American Geographers, 94(4): 848867 
Geraghty, R. M. (2007) 'The Impact of Globalization in the Roman Empire, 200 BC-AD 100', The Journal of Economic History, 67(4): 1036-1061

Gwynne, R. N. (2008) 'UK Retail Concentration, Chilean Wine Producers and Value Chains', The Geographical Journal, 174(2): 97-108

Hancock, D. (1998) 'Commerce and Conversation in the Eighteenth-Century Atlantic: The Invention of Madeira Wine', The Journal of Interdisciplinary History, 29(2): 197-219

Hancock, D. (2005) 'The Trouble with Networks: Managing the Scots' Early-Modern Madeira Trade', The Business History Review, 79(3): 467-491

Hannickel, E. (2013) Empire of Vines: Wine Culture in America, Philadelphia: University of Pennsylvania Press

Harvey, D. (2007) A Brief History of Neo-Liberalism, Oxford: Oxford University Press

Heath, D. and Meneley, A. (2007) 'Techne, Technoscience, and the Circulation of Comestible Commodities: An Introduction', American Anthropologist, 109(4): 593-602

Held, D. et al (1999) Global Transformations: Politics, Economics and Culture, Cambridge: Polity

Helzer, J. J. (2001) 'Old Traditions, New Lifestyles: The Emergence of a Cal-Ital Landscape', Yearbook of the Association of Pacific Coast Geographers, 63: 49-62

Hingley, R. (ed.) (2005) Globalizing Roman Culture: Unity, Diversity and Empire, London: Routledge

Hyams, E. (1965) Dionysus: A Social History of the Wine Vine, London: Thames and Hudson

Ho, H. K. (2019) 'The Globalization of the Wine Industry in Hong Kong: A Local and Global Perspective' in Inglis, D. and Almila, A.-M. (eds.) (2019) The Globalization of Wine, London: Bloomsbury

Inglis (2019a) 'Mutating and Contested Languages of Wine: Heard on the Grapevine' in S. D. Brunn and Kehrein, R. (eds.) Handbook of the Changing World Language Map, Basel: Springer

Inglis, D. (2019b) 'Wine Globalization: Longer-Term Dynamics and Contemporary Patterns' in Inglis, D. and Almila, A.-M. (eds.) The Globalization of Wine, London: Bloomsbury

Inglis, D. and Almila, A.-M. (2019) 'Introduction: The Travels and Tendencies of Wine' in Inglis, D. and Almila, A.-M. (eds.) The Globalization of Wine, London: Bloomsbury

Inglis, D. and Robertson, R. (2004) 'The Global Animus: In the Tracks of WorldConsciousness', Globalizations, 1(1): 38-49

Johnson, H. (1989) Vintage: The Story of Wine, New York: Simon and Schuster 
Kassam, A. and Davis, N. (2017) 'Evidence of world's earliest winemaking uncovered by archaeologists', https://www.theguardian.com/science/2017/nov/13/evidence-of-worldsearliest-winemaking-uncovered-by-archaeologists

Kjellgren, B. (2019) 'Fluid Modernity: Wine in China' in Inglis, D. and Almila, A.-M. (eds.) (2019) The Globalization of Wine, London: Bloomsbury

Lagendijk, A. (2004) 'Global "Lifeworlds" Versus Local "Systemworlds": How Flying Winemakers Produce Global Wines in Interconnected Locales', Journal of Economic and Social Geography, 95(5): 511-526

Laudan, R. (2004) 'Slow Food: The French Terroir Strategy, and Culinary Modernism', Food, Culture and Society, 7(2): 133-144

Lukacs, P. (2002) Inventing Wine, New York: W. W. Norton

Matthews, M. A. (2015) Terroir and Other Myths of Winegrowing, Berkeley: University of California Press

McGovern, P. (2003) Ancient Wine: The Search for the Origins of Viniculture, Princeton: Princeton University Press

Meneley, A. (2007) 'Like an Extra Virgin', American Anthropologist, 109(4): 678-687

Millon, M. (2013) Wine: A Global History, London: Reaktion

Montanari, M. (1996) The Culture of Food, Oxford: Blackwell

Murray, S. (2007) Moveable Feasts: The Incredible Journeys of the Things We Eat, London: Aurum

Nossiter, J. (2009) Liquid Memory: Why Wine Matters, London: Atlantic

Parker, T. (2015) Tasting French Terroir: The History of an Idea, Berkeley: University of California Press

Peck, G. (2009) The Prohibition Hangover: Alcohol in America from Demon Rum to Cult Cabernet, New Brunswick: Rutgers University Press

Phillips, R. (2000) A Short History of Wine, London: HarperPerennial

Pinilla, V. and Ayuda, M.-A. (2002) 'The Political Economy of the Wine Trade: Spanish Exports and the International Market, 1890-1935', European Review of Economic History, 6(1): $51-85$

Pinney, T. (2005) A History of Wine in America: From the Beginnings to Prohibition, University of California Press 
Pont, P. C. A. M. and Thomas, H. (2012) 'The Sociotechnical Alliance of Argentine Quality Wine: How Mendoza's Viticulture Functions Between the Local and the Global', 'Science, Technology, \& Human Values, 37(6): 627-652

Ritzer, G. (2007) The McDonaldization of Society, Los Angeles: Sage

Robertson, R. (1992) Globalization: Social Theory and Global Culture, London: Sage

-(1994) 'Globalisation or Glocalisation?', Journal of International Communication, 1(1): 3352

-(1995) 'Globalization: Time-Space and Homogeneity-Heterogeneity' in Featherstone, M., Lash, S. and Robertson, R. (eds.) Global Modernities, London: Sage: 25-44

-(2015) 'Beyond the Discourse of Globalization', Glocalism, 2015(1)

http://www.glocalismjournal.net/issues/global-polity-and-policies/articles/beyond-thediscourse-of-globalization-by-r-robertson.kl

Roudometoff, V. (2015) 'Theorizing Glocalization: Three Interpretations', European Journal of Social Theory, 19(3): 391-408

Sassen, S. (2001) The Global City: London, New York, Tokyo, Princeton: Princeton University Press

Serventi, S. and Sabban, F. (2002) Pasta: The Story of a Universal Food, New York: Columbia University Press

Simpson, J. (2011) Creating Wine: The Emergence of a World Industry, 1840-1914, Princeton: Princeton University Press

Soyer, A. (2004 [1853]) Pantropheon: Food, Cooking and Dining in Ancient Times, Mineola: Dover

Sweetman, R. J. (2007) 'Roman Knossos: The Nature of a Globalized City', American Journal of Archaeology, 111(1): 61-81

Taber, G. M. (2005) Judgment of Paris: California vs. France and the Historic 1976 Paris Tasting that Revolutionized Wine, New York: Scribner

Taplin, I. (2019) 'Building and Sustaining Legitimacy in an Emerging Wine Region: The Case of North Carolina, USA' in Inglis, D. and Almila, A.-M. (eds.) (2019) The Globalization of Wine, London: Bloomsbury

Trubek, A. B. (2004) 'Incorporating Terroir: L'Affaire Mondavi Reconsidered', Gastronomica, 4(3): 90-99

Turner, J. (2004) Spice: The History of a Temptation, London: Harper Perennial

Unwin, T. (1991) Wine and the Vine: An Historical Geography of Viticulture and the Wine Trade, London: Routledge 
Veseth, M. (2012) Wine Wars, Lanham: Rowman and Littlefield 